\title{
Photosynthetic Characteristics of Crested Wheatgrass and Bluebunch Wheatgrass
}

ROBERT S. NOWAK AND MARTYN M. CALDWELL

\section{Abstract}

Light and temperature dependencies for net photosynthesis and stomatal conductance were generally very similar between foliage on crested wheatgrass (A gropyron desertorum (Fisch. ex Link) Schult.) plants and that on bluebunch wheatgrass (A. spicatum (Pursh) Scribn. and Smith) plants. The similarity of these gas exchange characteristics between the 2 bunchgrass species was true for foliage on unclipped plants as well as on partially defoliated plants. However, light and temperature dependencies of senescing leaf blades that were exserted in late-spring were significantly different for unclipped plants of these $\mathbf{2}$ species. Photosynthetic rates and stomatal conductances of senescent late-season blades on bluebunch wheatgrass plants were greater than those on crested wheatgrass plants at light intensities greater than $0.8 \mathrm{mmol}$ photons $\mathrm{m}^{-2} \mathrm{~s}^{-1}$ (photosynthetic photon nux density) and at all foliage temperatures between $18^{\circ} \mathrm{C}$ and $41^{\circ} \mathrm{C}$. These greater photosynthetic rates and stomatal conductances do not mean that bluebunch wheatgrass tillers gained substantially more carbon or lost substantially more water than crested wheatgrass tillers. If both the photosynthetic area composition of tillers and the environmental conditions of the northern Utah study site were considered, carbon gain and water loss for individual bluebunch wheatgrass tillers would be very similar to those for individual crested wheatgrass tillers despite the significantly different responses to light and temperature during mid-summer.

Crested wheatgrass (Agropyron desertorum (Fisch. ex Link) Schult.) and bluebunch wheatgrass (A. spicatum ${ }^{l}$ (Pursh) Scribn. and Smith) are 2 rangeland species with diverse evolutionary histories (see Caldwell et al. 1981). There are important ecological differences between the 2 species, such as their abilities to tolerate grazing (Hyder 1974, Caldwell et al. 1981) and their tussock density (Cald well et al. 1983). However, they also have some very similar characteristics. Phenological patterns of foliage initiation, growth, and senescence are almost identical (Nowak and Caldwell 1984a, 1984b). Furthermore, net photosynthetic rates and optimal temperature and irradiance conditions are also very similar.

Photosynthetic rates at optimal environmental conditions may not accurately reflect the ability of a plant to fix carbon under natural conditions. Environmental conditions for optimal photosynthesis rarely occur. For example, Schulze and Hall (1982) found that the average photosynthetic rates of 3 species during the day were $30 \%$ to $70 \%$ less than the photosynthetic rates measured under optimal conditions. Furthermore, maximum photosynthetic rates were never observed in the field for 2 of the species. The amount of photosynthetic surface area can also be an important factor that affects the ability of plants to gain carbon (Caldwell et al. 1977, Potvin and Werner 1983, Wilson and Ludlow 1983).

Authors are assistant professor, Department of Range, Wildlife, and Forestry, University of Nevada Reno, 1000 Valley Road, Reno 89512; and professor, Department of Range Science, Utah State University, Logan, 84322. At the time of the research, the senior author was graduate research assistant, Department of Range Science, Utah State University.

The field assistance of $C$. Nowak and S. Vaniman are greatly appreciated. We also thank Dr. Jay E. Anderson, Idaho State University, for his careful review of the manuscript. This study was supported by the National Science Foundation (DEB 7907323 and DEB 8207171 ) and the Utah Agricultural Experiment Station.

Please address all reprint requests to $M$. Caldwell.

Manuscript accepted 26 December 1985.

Taxonomic revisions of the Triticear (Barkworth et al. 1983) suggest that the nomenclature for bluebunch wheatgrass be changed to Pseudoroegneria spicata (Pursh) A. Love.
Therefore, photosynthetic rates at a range of natural environmental conditions and a measurement of photosynthetic surface area would have to be considered before an ecologically meaningful inference can be drawn from gas exchange data.

The purpose of our study was to determine if the dependence of net photosynthesis and stomatal conductance on irradiance and foliage temperature differs between crested wheatgrass and bluebunch wheatgrass. If there were differences, then the ecological significance of those differences was considered with respect to the environmental conditions that occur in the field and also to the amount of photosynthetic surface area on tillers. Photosynthetic surface area and light and temperature dependencies of photosynthesis and conductance were measured on undefoliated, intact plants of both species throughout the growing season. These measurements were also obtained from partially defoliated plants.

\section{Methods}

Gas exchange of crested wheatgrass and bluebunch wheatgrass foliage elements was measured on plants that were growing at a field study site near Logan, Utah. This study site is on a bench area (1,460 m elevation) that was formerly occupied by bluebunch wheatgrass and is also typical of areas seeded to crested wheatgrass. A complete description of the study site is found in Caldwell et al. (1981). A pool of 20-25 plants was used for the gas exchange measurements of each species-treatment combination.

$\mathrm{ACO}_{2}$-compensation gas exchange system (Bingham and Coyne 1977) and an infrared gas analyzer (Analytical Designs Corp., Ltd.) were used to measure $\mathrm{CO}_{2}$ and water vapor fluxes of individual foliage elements, our unit of reference and replication. In this paper, we use the term "blade" for leaf blade or lamina, "sheath" for leaf sheath, "stem" for the stem of a grass tiller, and "foliage" or "foliage element" as generic terms for all 3 plant parts (see Thomas 1980, Nowak and Caldwell 1984a). Net photosynthetic rates and stomatal conductances were calculated with equations that were expanded from those of Caemmerer and Farquhar (1981) and are reported as molar fluxes per unit surface area. Area of a blade was the projected area of one side of the blade. An equivalent "one side" area of a sheath or stem was computed by multiplying the projected area of sheaths and stems by $\mathrm{pi} / 2$; this calculation yields one-half of the cylindrical surface area of sheaths and stems. Projected area was measured with an area meter (LiCor Corp. Model LI-3000).

Light and temperature dependencies of net photosynthesis and stomatal conductance were measured on individual foliage elements from April through July, 1980 and 1981 . The basic protocol for determination of the dependencies was to measure gas exchange at a series of light and temperature steps. Light intensity was manipulated by shading the cuvette with neutral density filters. Different temperatures were achieved by varying the cuvette air temperature, which caused a change in foliage temperature. Selection of the light and temperature levels was based on typical $\mathrm{C}_{3}$ light and temperature dependencies (e.g., Larcher 1980). Gas exchange measurements were made at high and low levels of light or temperature plus more intensive sampling at levels where photosynthesis changed most rapidly. For example, a light dependency consisted of measurements at photosynthetic photon flux densities (PPFD) of 2.0 (full sunlight), 1.5, 1.0, 0.8, 0.4, and $0.15 \mathrm{mmol}$ photons $\mathrm{m}^{-2} \mathrm{~s}^{-1}$. A typical temperature dependency during the first part of the spring was measurements at $14,18,21,25,28$, and $35^{\circ} \mathrm{C}$ 
foliage temperature; during the second half of the spring, the $14^{\circ} \mathrm{C}$ temperature step was replaced with a $41^{\circ} \mathrm{C}$ temperature. After initial characterization of the light and temperature dependencies of the $\mathbf{2}$ species, the number of sample points per dependency was reduced. This was done in order to increase the number of foliage elements that could be sampled in a given time period, and therefore allow a more complete characterization of all foliage elements and a statistical comparison among the species and treatments. Almost two thirds of the dependencies consisted of measurements at 5 light or temperature levels; 4-, 6-, and 7-point dependencies made up approximately $15 \%, 15 \%$, and $5 \%$ of the total number of dependencies, respectively.

Except for the foliage-to-air water vapor gradient, other environmental parameters were held relatively constant during determination of each dependency. The temperature of the foliage element was maintained near $22^{\circ} \mathrm{C}$ during the determination of light dependencies. (For an individual light dependency, foliage temperature varied less than $4^{\circ} \mathrm{C}$; for all dependencies, the foliage temperature was between $20^{\circ} \mathrm{C}$ and $28^{\circ} \mathrm{C}$ ). Temperature dependencies of gas exchange parameters were measured at PPFD levels above saturating irradiance. The water vapor gradient from the foliage to the air was kept constant during determination of light dependencies. (For an individual light dependency, the variation of the water vapor gradient was usually less than $4 \mathrm{mb}$; for all dependencies, the water vapor gradient was between 17 and $35 \mathrm{mb}$.) However, the water vapor gradient was allowed to increase as foliage temperature was increased because a concomitant increase in the water vapor gradient naturally occurs as air and foliage temperature increase during the daytime. The $\mathrm{CO}_{2}$ concentration of the gas exchange cuvette was maintained near ambient levels as both PFFD and foliage temperature were varied. (For an individual dependency, cuvette $\mathrm{CO}_{2}$ concentration typically varied by $4 \mu \mathrm{l}$ $1^{-1}$; for all dependencies, cuvette $\mathrm{CO}_{2}$ concentrations were between 0.315 and $0.349 \mathrm{ml} \mathrm{1}^{-1}$.)

Light and temperature dependencies for leaf blades on undefoliated plants were sorted into groups that were based on the phenological stage and season of blade initiation. Blades were divided into 2 phenological groups, mature and senescent, because large changes in the light and temperature dependencies only occurred as blades became senescent (see Results). The mature group consisted of fully expanded blades and the senescent group consisted of blades that had a senescent distal portion $(20 \mathrm{~mm}$ or more in length) but a green basal portion ( $0.1 \mathrm{~m}$ or more in length) (see Nowak and Caldwell 1984a). We also grouped blades according to the season of initiation: blades that were initiated early in the spring growing season (early-season) and those initiated later in the spring (late-season). The early-season blades were initiated from mid-February through early-April, and the late-season blades were initiated from mid-April through late-May. This sorting resulted in 4 groups of leaf blades on undefoliated plants of each species: mature early-season blades, senescent early-season blades, mature late-season blades, and senescent late-season blades.

The light and temperature dependencies for blades on partially defoliated plants were sorted into seasonal-phenological groups comparable to those on unclipped plants. Data for foliage on clipped plants were not as extensive as those for control plants. Light dependencies of foliage on partially defoliated plants were measured for mature early-season blades, senescent early-season blades, and mature late-season blades. Temperature dependencies were measured only for mature late-season blades on partially defoliated plants. Data from foliage on clipped plants were collected in 1980, when plants were severely defoliated 2 times $(50-\mathrm{mm}$ stubble height, see Caldwell et al. 1981), and in 1981, when plants were moderately defoliated 3 times (removed $50 \%$ of the standing crop, see Nowak and Caldwell 1984a).

Light and temperature dependencies for sheaths and stems were measured in June and July, after these foliage elements were fully expanded. Gas exchange measurements of sheaths and stems were impossible before June because the sheath and stem segments were too short to fit in the cuvette. On undefoliated plants, both light and temperature dependencies for sheaths and stems were determined. However, only light dependencies for sheaths and stems were measured on partially defoliated plants.

The light and temperature dependencies of net photosynthesis were considered as significantly different between the 2 species only if 3 sequential statistical tests indicated significant differences. Before the first test, second-order polynomial regressions of net photosynthesis versus PPFD and net photosynthesis versus foliage temperature were determined for data sets from each phenologicalseasonal group of foliage elements. The first statistical test determined if the regression equation of 1 species was significantly different from that of the other species for each foliage group (Neter and Wasserman 1974). If there were significant differences between species for the second-order regressions, then a Student's ' $t$ ' test was used to compare net photosynthetic rates within discrete ranges of PPFD and foliage temperature. This test indicated that ranges of irradiance and temperature over which the photosynthetic rates of 1 species were significantly different from those of the other species. The final statistical test determined if certain characteristics of the light and temperature dependencies for net photosynthesis were significantly different between species. Before the third statistical test, net photosynthetic rates from each individual series of temperature steps were fit to a second-order regression and rates from each individual series of PPFD steps were fit to the Smith equation (Smith 1937). The characteristics of the temperature dependency considered particularily meaningful were the optimum temperature for net photosynthesis, the high temperature compensation point for photosynthesis, and photosynthetic rate at the temperature optimum. These were calculated from each individual regression equation. For the light dependency, the initial slope of the light curve and the photosynthetic rate at saturating irradiance were the characteristics calculated from each individual Smith equation. Values for a given characteristic from individual equations were grouped into sample populations that corresponded to each phenological-seasonal group of foliage elements. A Student's ' $t$ ' test determined if the characteristic from one species was significantly different from the other species. Results of the statistical tests were considered significant if $p<0.05$.

Statistical analysis of the light and temperature dependencies for stomatal conductance utilized only the first and second statistical tests that were used for the net photosynthetic data. Also, linear regressions of stomatal conductance versus temperature were determined before the first test rather than second-order regressions. Further discussion of the statistical procedures is found in Nowak (1984).

In addition to the gas exchange data, measurements of air temperature and PPFD were also collected at the study site. Air temperature was measured with a fine-wire thermocouple, and PPFD was determined with a quantum sensor (LiCor Corp., Model LI-10SB). Dew point temperature of the air was available from data collected at an official weather station that was within 2 $\mathrm{km}$ of the study site.

The green surface area per tiller of foliage elements was periodically measured from late-February to late-July, 1981, by destructive harvest (see Nowak and Caldwell 1984a). The growing season was divided into 4 time spans: 27 February to 10 April, 11 April to 17 May, 18 May to 22 June, and 23 June to 20 July. These particular dates correspond to dates of destructive harvests, but the time spans correspond to periods of growth or senescence for groups of foliage elements. During the period of 27 Febuary to 10 April, early-season blades finished expanding and late-season blades were initiated. During the period of 11 April to $17 \mathrm{May}$, early-season blades were fully expanded, late-season blades finished expanding, and culm elongation was initiated. Culm elongation continued during the time periods of 18 May to 22 June and 23 June to 20 July. Senescence of early-season blades occurred during 
the time period of 18 May to 22 June, and late-season blades senesced during the period of 23 June to 20 July.

\section{Results}

\section{Mature Late-season Leaf Blades}

Light dependencies of net photosynthesis and stomatal conductance are shown in Figure 1 for leaf blades that were initiated between mid-April and late-May. For both species, stomatal response to a decrease in light intensity was not proportional to the photosynthetic response. Although photosynthetic rates at saturating irradiance of bluebunch wheatgrass blades tended to be slightly higher than those of crested wheatgrass blades, the difference was not significant. Photosynthetic rates at low irradiance levels were very similar between species for mature late-season blades.

Temperature dependencies of gas exchange parameters for mature late-season blades are given in Figure 2. There was a curvilinear photosynthetic response to an increase in blade temperature, but stomatal conductance decreased almost linearly as blade temperature increased. Concomitant with the increase in temperature, the water vapor gradient from foliage to air also increased. At blade temperatures less than $24^{\circ} \mathrm{C}$, the stomatal conductance of mature late-season blades on bluebunch wheatgrass plants was significantly greater than that on crested wheatgrass plants. However, stomatal conductances of the $\mathbf{2}$ species were not significantly different at higher blade temperatures. Net photosynthetic rates were not significantly different between species at any blade temperature. Finally, the optimal temperature for net photosynthesis and the high temperature compensation point for photosynthesis were nearly identical for both bunchgrass species.

\section{Senescent Late-season Leaf Blades}

When late-season blades were senescent, responses of gas exchange parameters to changes in irradiance were reduced (Fig. 3), relative to mature late-season blades. For both species, net photosynthetic rates of senescent late-season blades were considerably lower than those of mature late-season blades at saturating light intensities. At all irradiance levels, stomatal conductance of senescent blades on bluebunch wheatgrass plants was significantly greater than those on crested wheatgrass plants. Net photosynthetic rates of senescent bluebunch wheatgrass blades were significantly greater than those of crested wheatgrass only at light intensities greater than $0.8 \mathrm{mmol}$ photons $\mathrm{m}^{-2} \mathrm{~s}^{-1}$ PPFD.

Net photosynthesis and stomatal conductance of senescent bluebunch wheatgrass blades were significantly greater than those of senescent crested wheatgrass blades at all blade temperatures (Fig. 4). The high temperature compensation point for net photosynthesis of senescent bluebunch wheatgrass blades was significantly greater than that of senescent crested wheatgrass blades. The high temperature compensation point of senescent bluebunch wheatgrass blades was also higher than that of mature bluebunch wheatgrass blades, but an increase in the high temperature compensation point was not observed as crested wheatgrass blades aged. The optimal temperature for photosynthesis was not significantly different between species for senescent late-season blades, but the optimal temperature of senescent blades was about $3^{\circ} \mathrm{C}$ greater

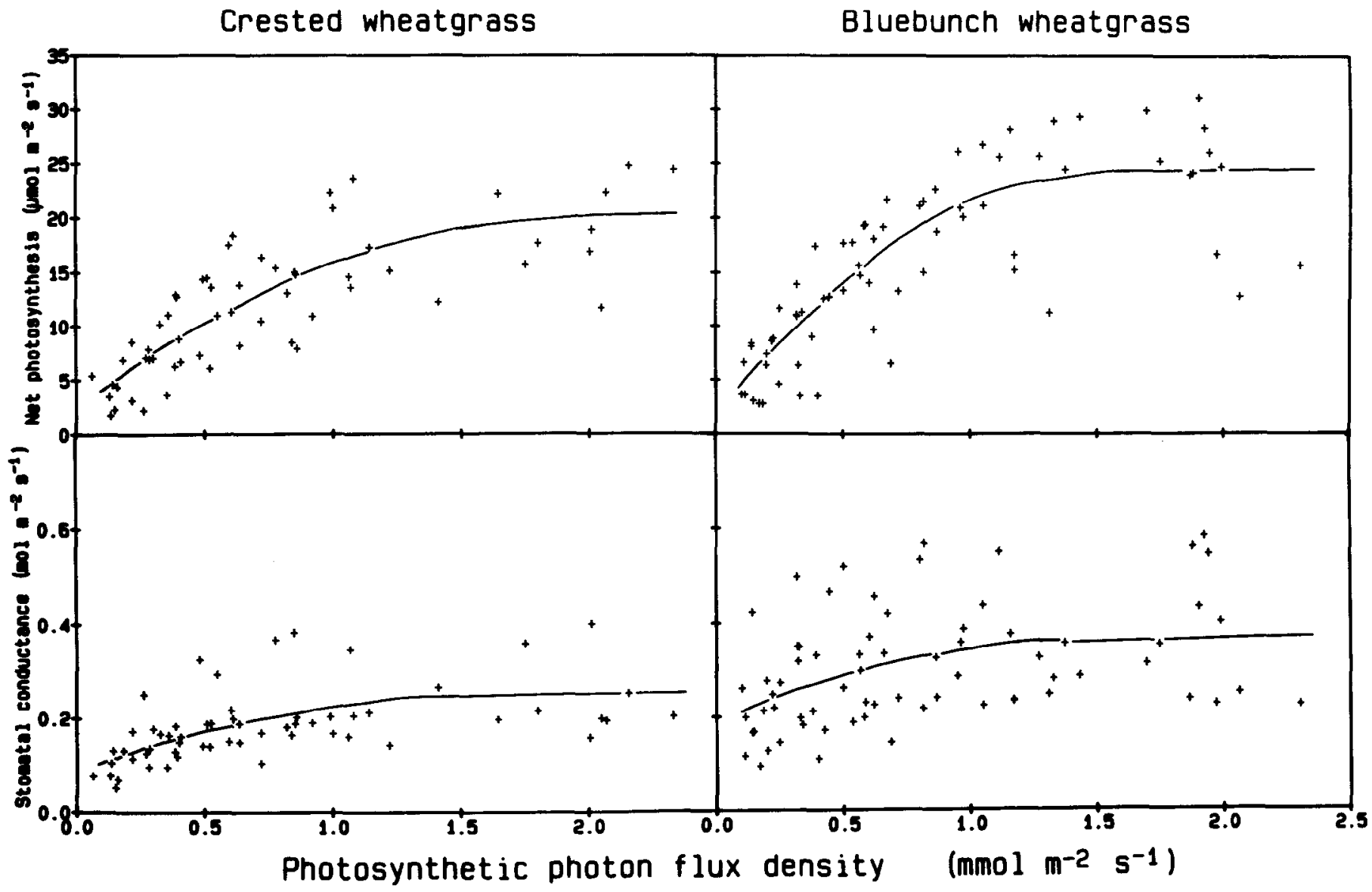

Fig. 1. Light dependencies of net photosynthesis and stomatal conductance for mature (fully expanded) late-season leaf blades. Gas exchange was determined for 12 crested wheatgrass and 15 bluebunch wheatgrass blades between late-April and mid-June. Light dependencies were measured as irradiance was decreased. Blade temperature was maintained near $22^{\circ} \mathrm{C}$, and cuvette $\mathrm{CO}_{2}$ concentration and water vapor gradient conditions are described in the Methods. All regressions are significant at $\mathrm{p}<0.01$. For crested wheatgrass photosynthesis, $\mathrm{r}^{2}=0.64 ;$ for bluebunch wheatgrass photosynthesis, $\mathrm{r}^{2}=0.69 ;$ for crested wheatgrass conductance, $\mathrm{r}^{2}=0.31$; and for bluebunch wheatgrass conductance, $\mathrm{r}^{2}=0.14$. 


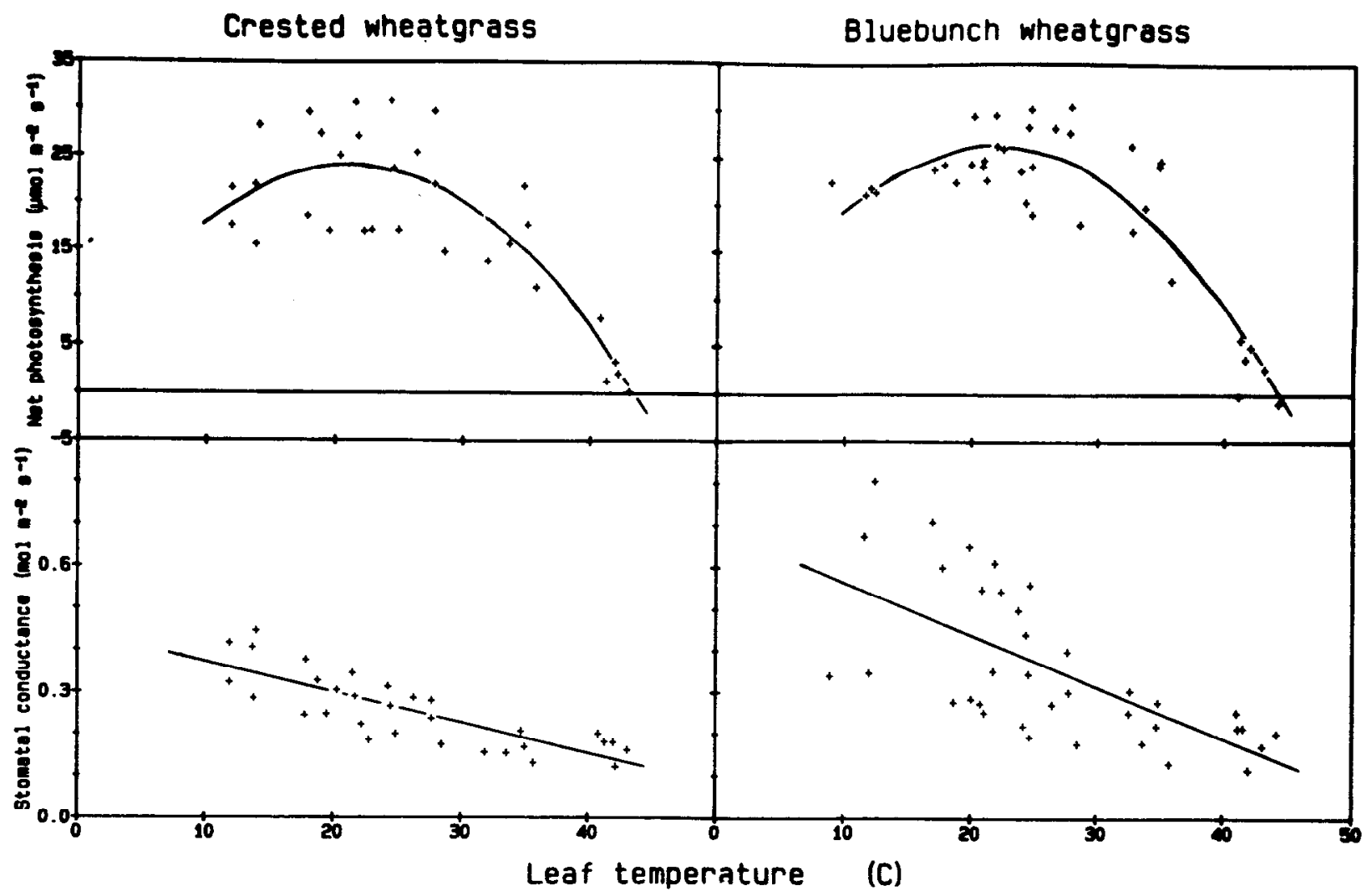

Fig. 2. Temperature dependencies of gas exchange parameters for mature late-season leaf blades. Net photosynthesis and stomatal conductance were measured for 5 crested wheatgrass and 7 bluebunch wheatgrass blades between late-April and mid-June. Gas exchange was measured as foliage temperature and water vapor gradient were increased concomitantly. Irradiance was maintained above saturating intensities, and other cuvette conditions are described in the Methods. All regressions are significant at $\mathrm{p}<0.01$. For crested wheatgrass photosynthesis, $\mathrm{r}^{2}=0.71 ;$ for bluebunch wheatgrass photosynthesis, $\mathrm{r}^{2}=0.81$; for crested wheatgrass conductance, $\mathrm{r}^{2}=0.64$; and for bluebunch wheatgrass conductance, $\mathrm{r}^{2}=0.42$.

\section{Crested wheatgrass Bluebunch wheatgrass}

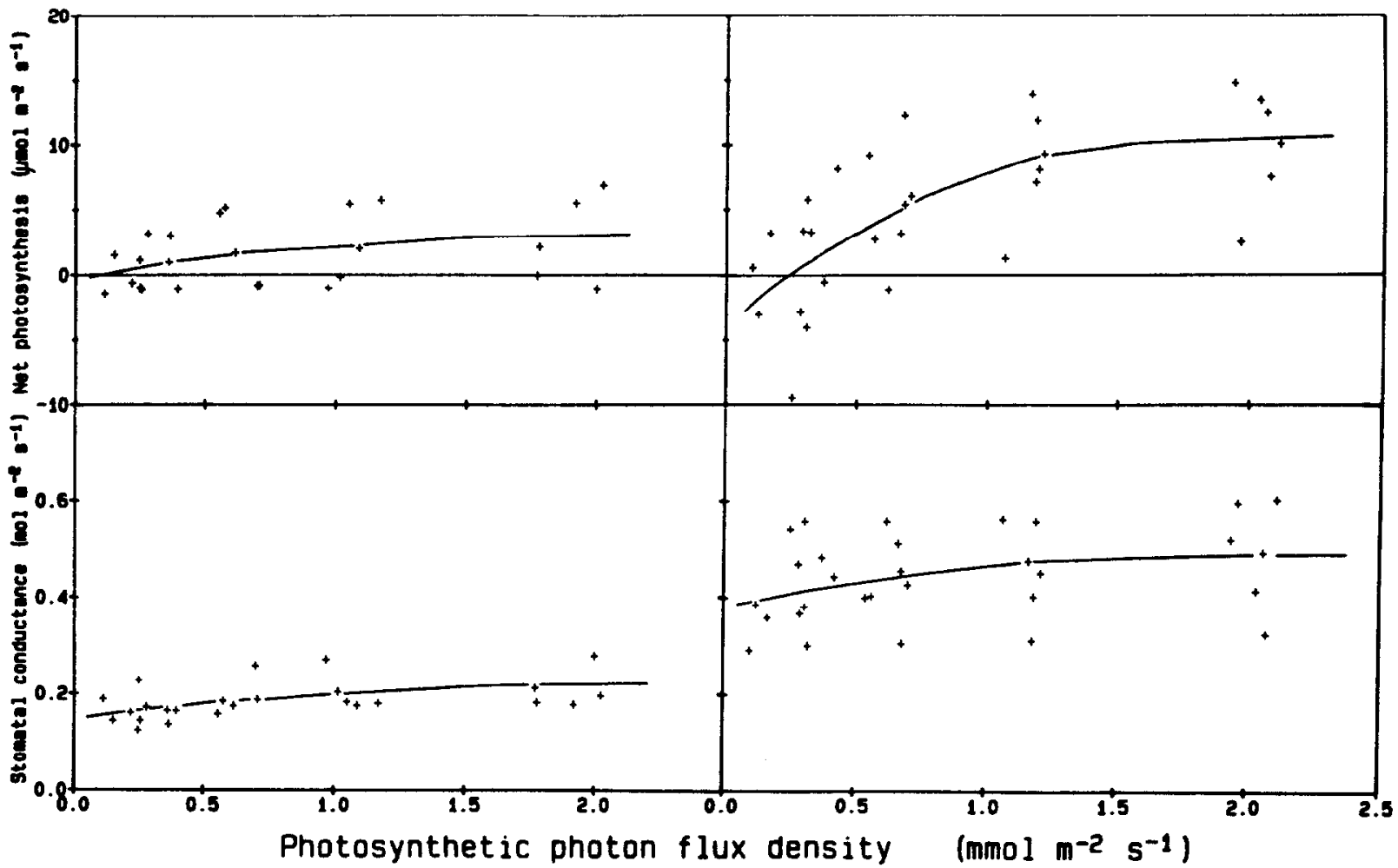

Fig. 3. Light dependencies of gas exchange parameters for senescent late-season leaf blades. Gas exchange was determined for 5 crested wheatgrass and 6 bluebunch wheatgrass blades between mid-June and late-July. Chamber and foliage environmental conditions are described in Methods. Regressions for bluebunch wheatgrass photosynthesis and crested wheatgrass conductance are significant at p $<0.05 ;$ the other 2 regressions are not significant. For bluebunch wheatgrass photosynthesis, $\mathrm{r}^{2}=0.44$; and for crested wheatgrass conductance, $\mathrm{r}^{2}=0.16$. 


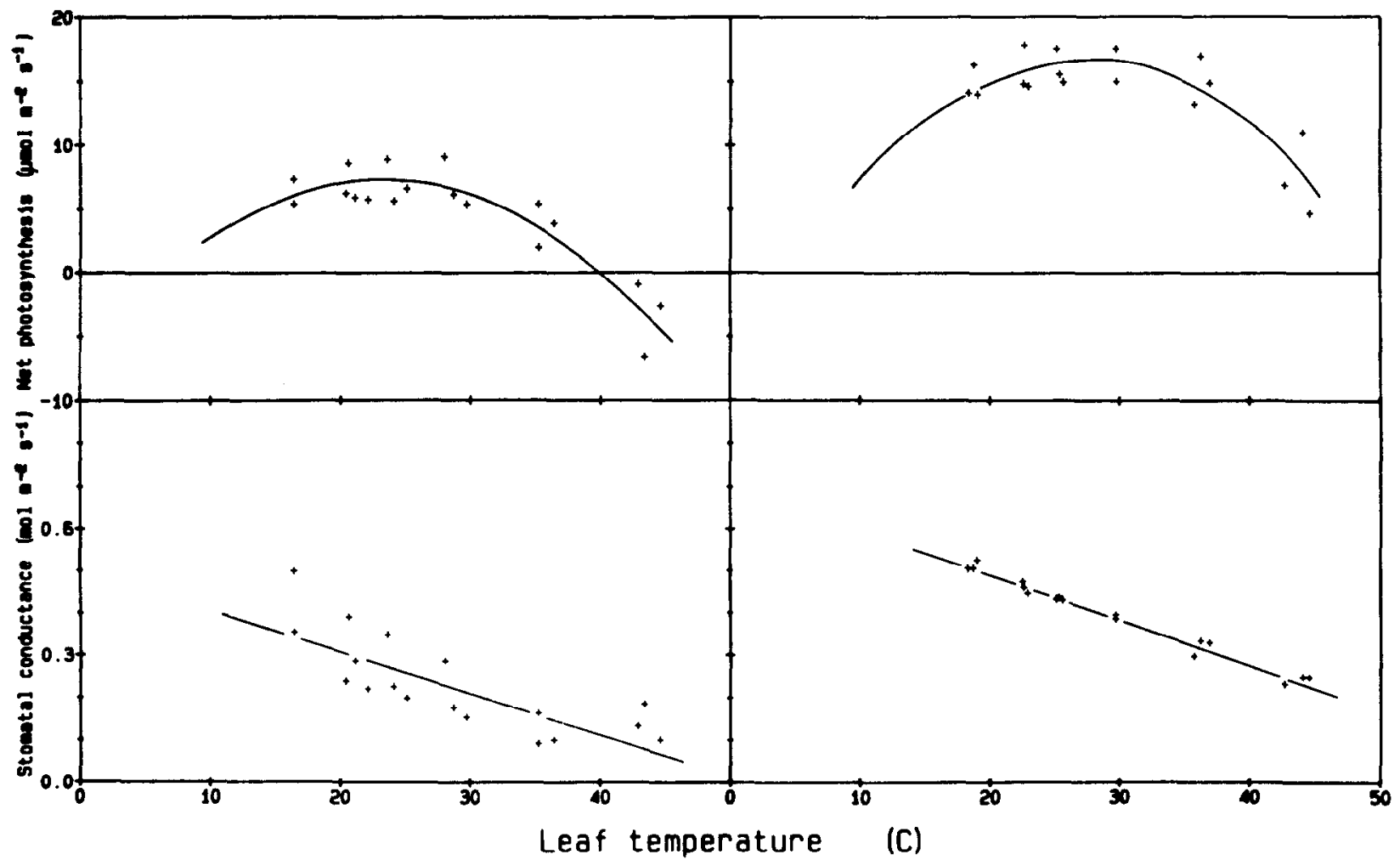

Fig. 4. Temperature dependencies of net photosynthesis and stomatal conductance for senescent late-season leaf blades. Gas exchange parameters were measured on 3 crested wheatgrass and 3 bluebunch wheatgrass blades between mid-June and late-July. Cuvet te conditions are described in the Methods. All regressions were significant at $\mathrm{p}<0.01$. For crested wheatgrass photosynthesis, $\mathrm{r}^{2}=0.83$; for bluebunch wheatgrass photosynthesis, $\mathrm{r}^{2}=0.71$; for crested wheatgrass conductance, $\mathrm{r}^{2}=0.59 ;$ and for bluebunch wheatgrass conductance, $\mathrm{r}^{2}=0.98$.

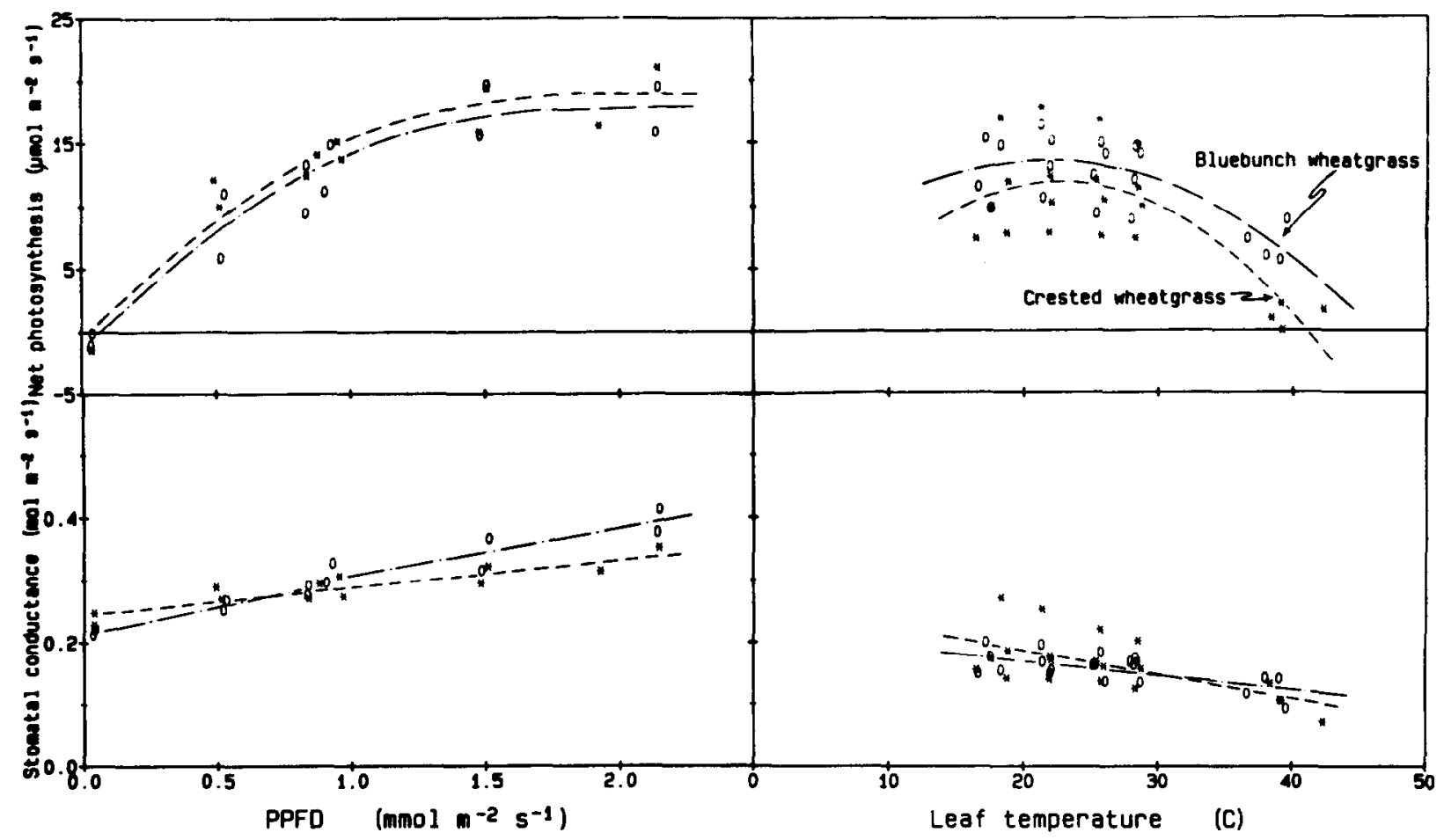

Fit. 5. Light and temperature dependencies of gas exchange parameters for mature sheaths and stems measured from mid-June to early-July. Gas exchange was measured at cuvette conditions described in Methods. Gas exchange was determined for 4 sheaths and stems (2 from each species) for light dependencies, and 8 sheaths and stems (4 from each species) for temperature dependencies. All regressions are significant at p<0.01. For light dependencies: crested wheatgrass photosynthesis, $\mathrm{r}^{2}=0.90 ;$ bluebunch wheatgrass photosynthesis, $\mathrm{r}^{2}=0.90$; crested wheatgrass conductance, $\mathrm{r}^{2}=0.77 ;$ and bluebunch wheatgrass conductance, $\mathrm{r}^{2}=0.90$. For temperature dependencies: crested wheatgrass photosynthesis, $\mathrm{r}^{2}=0.56 ;$ bluebunch wheatgrass photosynthesis, $\mathrm{r}^{2}=0.50$; crested wheatgrass conductance, $\mathrm{r}^{2}=0.37$; and bluebunch wheatgrass conductance, $\mathrm{r}^{2}=0.38$. 


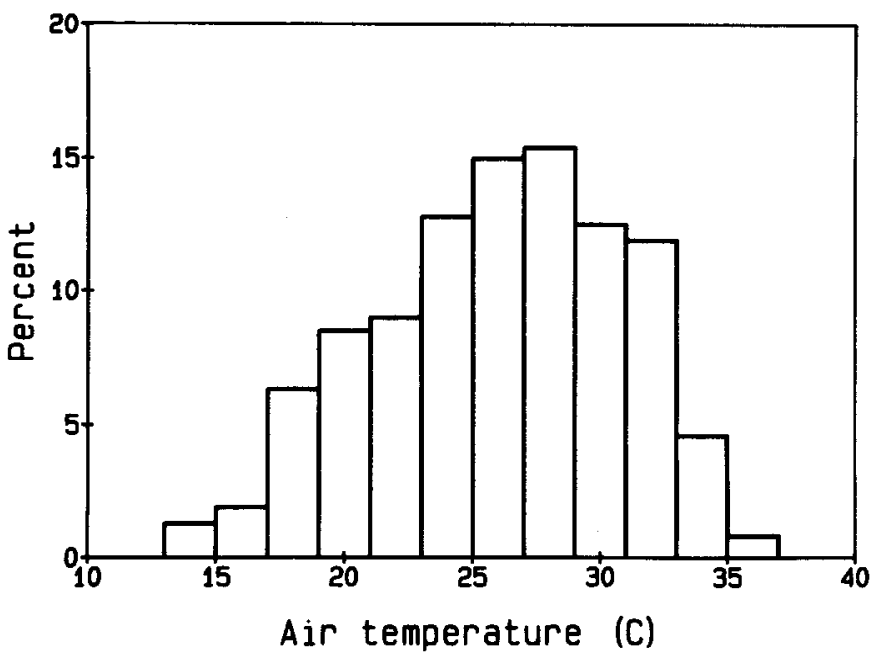

Fig. 6. Percent of time when irradiance exceeded 0.8 mmol photons $m^{-2} s^{-1}$ that the air temperature fell in temperature ranges. Percentages were calculated from concomitant measurements of air temperature and irradiance at the field study site between 22 June and $31 \mathrm{July}$, in each of the 3 years 1980, 1981, and 1982.

than that of mature blades.

\section{Sheaths and Stems}

Green sheath and stem foliage elements are photosynthetically active. The light and temperature dependencies for mature sheaths and stems are shown in Figure 5. The light dependencies of all gas exchange parameters were not significantly different between species. Stomatal conductances at all foliage temperatures and net photosynthetic rates at temperatures below $30^{\circ} \mathrm{C}$ were also not significantly different between species. However, the high temperature compensation point for net photosynthesis of mature bluebunch wheatgrass sheaths and stems was significantly greater than that of mature crested wheatgrass sheaths and stems.

\section{Early-season Leaf Blades}

The light and temperature dependencies of gas exchange parameters were also measured for blades that were exserted early in the spring. Data for these early-season blades are not shown, but the light and temperature dependencies for mature and senescent blades of both species were equivalent to those for late-season blades on bluebunch wheatgrass plants at the respective phenological stage. Light and temperature dependencies of all gas exchange parameters were not significantly different between species for mature early-season blades as well as for senescent early-season blades. Changes in light and temperature dependencies that occurred as late-season blades became senescent, such as flattened light dependencies and lower net photosynthetic rates at saturating irradiance, were also observed as the early-season blades became senescent.

\section{Foliage on Clipped Plants}

Partial defoliation did not change the relative differences between species for light and temperature dependencies (data not shown). For example, the light dependencies of all gas exchange parameters were not significantly different between species for both mature and senescent early-season blades on partially defoliated plants. For mature late-season blades on clipped plants, stomatal conductances of bluebunch wheatgrass blades were significantly higher than those of crested wheatgrass blades at low blade temperatures and all light intensities, which was also observed for mature late-season blades on unclipped plants (Figs. 1 and 2). Light and temperature dependencies of photosynthesis were not significantly different between species for mature lateseason blades on clipped plants. Finally, the light dependencies of

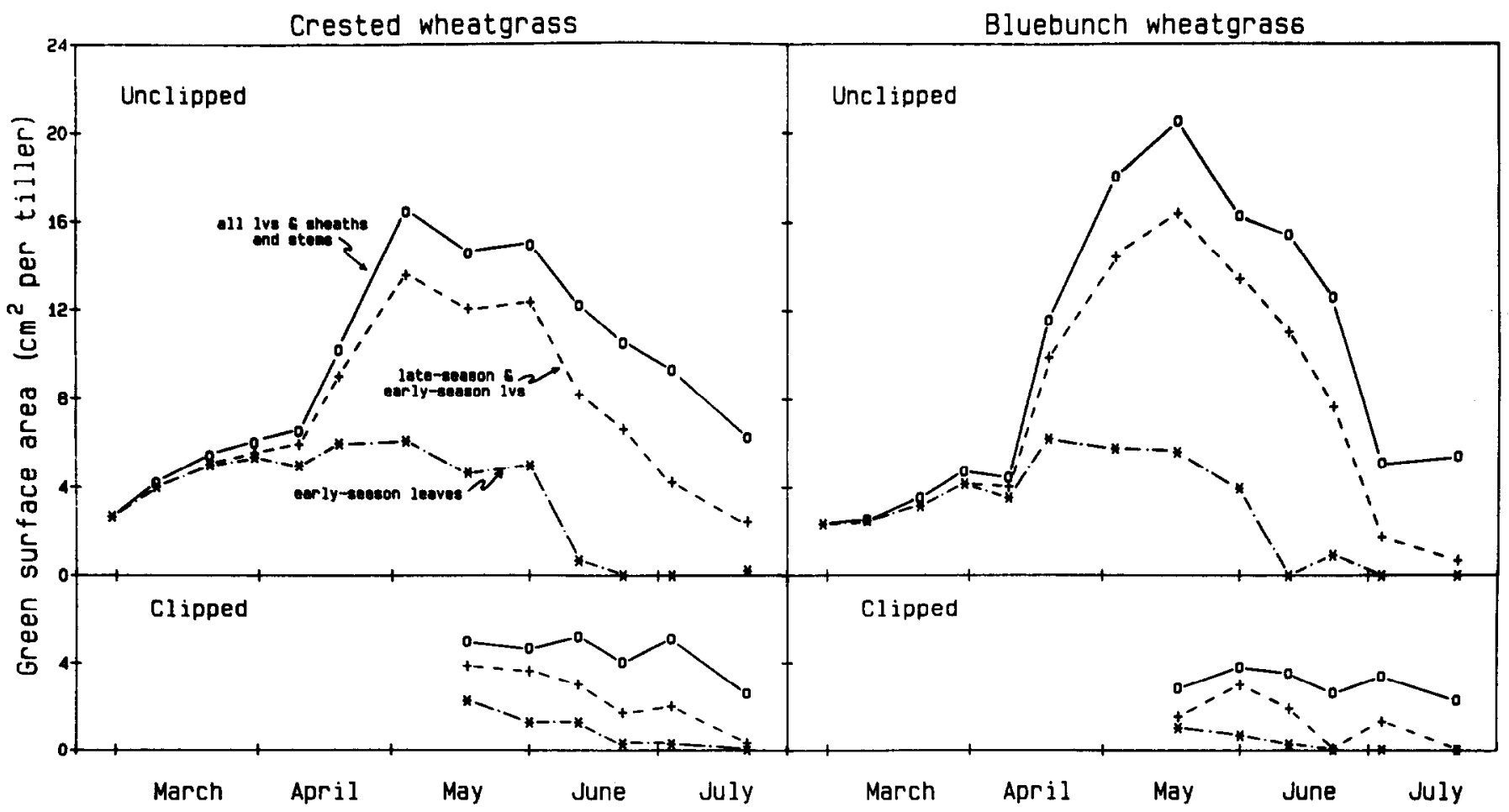

Fig. 7. Average green surface area per tiller for early-season leaf blades, for early-season blades plus late-season blades, and for all blades plus sheaths and stems during 1981. Surface areas are expressed as "one-side" of a blade and one-half the actual surface area of a sheath or stem. Areas were determined from the destructive harvest of tillers on undefoliated plants and partially defoliated plants of both species. 
gas exchange parameters for mature sheaths and stems on partially defoliated plants were not significantly different between species, which was also observed for sheaths and stems on undefoliated plants (Fig. 5).

\section{Ambient Air Temperature}

Meteorological data, which were collected at or near the study site, were analyzed for the time period when gas exchange differences between species were the largest. This time period was a 40-day period from 22 June to 31 July when late-season blades were senescing. Because photosynthetic rates and stomatal conductances of senescent late-season blades on bluebunch wheatgrass plants were significantly greater than those on crested wheatgrass plants at irradiances greater than $0.8 \mathrm{mmol} \mathrm{m}^{-2} \mathrm{~s}^{-1}$ PPFD (Fig. 3), meteorological data were summarized only during these periods of the day (Fig. 6). For 30\% of the time when PPFD exceeded 0.8, air temperature was between 25 and $29^{\circ} \mathrm{C}$; for over $75 \%$ of the time that PPFD was greater than 0.8 , air temperature was between 23 and $33^{\circ} \mathrm{C}$. The dew point temperature did not change appreciably during this 40 -day period; the average dew point was $8^{\circ} \mathrm{C}$, as determined from 5 years of data at an official weather station within $2 \mathrm{~km}$ of the study site.

\section{Green Surface Area}

The total green surface area per tiller on unclipped crested wheat grass plants was $30 \%$ to $40 \%$ greater than that on unclipped bluebunch wheatgrass plants during the time periods of 27 February to 10 April and 23 June to 20 July (Fig. 7). However, the total green surface area per tiller on unclipped bluebunch wheatgrass plants was $15 \%$ to $20 \%$ greater than that on unclipped crested wheatgrass plants during the 2 time periods between 11 April and 22 June. During the period of 27 February and 10 April, earlyseason blades accounted for almost $90 \%$ of the total green surface per tiller on unclipped plants of both species; and the average green surface area per tiller for these early-season blades on unclipped crested wheatgrass plants was about $40 \%$ greater than that on unclipped bluebunch wheatgrass plants. However, during the remainder of the growing season, the average green surface area per tiller for early-season blades was very similar between the 2 species. The average green surface area per tiller for late-season blades and sheaths and stems on unclipped bluebunch wheatgrass plants was $20 \%$ to $35 \%$ greater than those on unclipped crested wheatgrass plants during the 2 periods between 11 April and 22 June. During the final time period, the average green surface area per tiller for late-season blades and for sheaths and stems on unclipped crested wheatgrass plants were $75 \%$ and $5 \%$ greater, respectively, than those on unclipped bluebunch wheatgrass plants. For each of the 3 groups of plant parts on partially defoliated plants, the average green surface area per tiller on clipped crested wheatgrass plants was consistently greater than that on clipped bluebunch wheatgrass plants.

\section{Discussion}

Although bluebunch wheatgrass and crested wheatgrass have different evolutionary histories, there are only a few differences between these species in their light and temperature dependencies of net photosynthesis and stomatal conductance. These dependencies for mature early-season blades, senescent early-season blades, mature late-season blades, and sheaths and stems on unclipped plants were very similar between the 2 bunchgrass species (Results; Figs. 1, 2, and 5). Light and temperature dependencies for foliage on partially defoliated plants were only available for these same 4 groups of foliage, and the dependencies on clipped plants paralleled those on unclipped plants.

Even though senescent late-season blades on unclipped plants were the only plant parts to have large differences between species for light and temperature dependencies of gas exchange parameters (Figs. 3 and 4), the ecological significance of higher net photosynthetic rates and stomatal conductances on unclipped bluebunch wheatgrass plants is not very great at this northern Utah location. Between blade temperatures of 15 and $35^{\circ} \mathrm{C}$, the photosynthetic rates of senescent late-season blades on bluebunch wheatgrass plants averaged almost 1.5 times greater than those on crested wheatgrass plants (Fig. 4). Stomatal conductances of the same blades on bluebunch wheatgrass plants averaged $66 \%$ greater than those on crested wheatgrass plants. However, the gas exchange differences between species for senescent late-season blades were smaller between 20 and $30^{\circ} \mathrm{C}$ than at low or high blade temperatures, and these are the most common temperatures between 22 June and 31 July (Fig. 6). Furthermore, net photosynthetic rates for senescent late-season blades on unclipped bluebunch wheatgrass plants were not significantly different from those on unclipped crested wheatgrass plants below $0.8 \mathrm{mmol}$ photons $\mathrm{m}^{-2} \mathrm{~s}^{-1}$ PPFD (Fig. 3). On a typical clear day, during late-June or July, approximately one third of the daylight hours were below $0.8 \mathrm{mmol}$ photons $\mathrm{m}^{-2} \mathrm{~s}^{-1}$, and foliage elements within the bunchgrass canopy would be shaded during many portions of the daylight when PPFD above the canopy exceeded 0.8 . Finally, during this time period after 22 June, surface area for late-season blades on unclipped bluebunch wheatgrass plants averaged $43 \%$ less than that on unclipped crested wheatgrass plants, and these blades comprised only $35 \%$ of the total green surface area per tiller on unclipped bluebunch wheatgrass plants and $47 \%$ of the total on unclipped crested wheatgrass plants (Fig. 7). Thus, when environmental conditions and photosynthetic surface areas at this northern Utah site are considered, the ecological significance of higher photosynthetic rates and stomatal conductances of senescent late-season blades on unclipped bluebunch wheatgrass plants is small. If the parallel of light and temperature dependencies on undefoliated plants with those on partially defoliated plants is extended to senescent lateseason blades, then a similar analysis of gas exchange and green surface area data for partially defoliated plants would yield the same conclusion.

Carbon gain and water loss of tillers on partially defoliated plants would be lower than those of tillers on undefoliated plants. Although net photosynthetic rates at optimal temperature and irradiance conditions for foliage on partially defoliated plants averaged $27 \%$ greater than those for foliage on undefoliated plants (Nowak and Cald well 1984a), the total green surface area per tiller on partially defoliated plants was $50 \%$ to $75 \%$ less than that on undefoliated plants (Fig. 7). Thus, the greater photosynthetic rates of foliage on partially defoliated plants did not completely compensate for the loss in photosynthetic tissue.

\section{Conclusions}

At a northern Utah study site, light and temperature dependencies of net photosynthesis and stomatal conductance were usually very similar between foliage from crested wheatgrass plants and foliage from bluebunch wheatgrass plants. When these two gas exchange characteristics were not similar between the 2 species, an assessment of prevailing environmental conditions and photosynthetic surface area composition of tillers indicates that the gas exchange differences between species would not result in large differences in carbon gain and water loss for individual tillers. Partial defoliation of plants did not appear to change the relative differences between the light and temperature dependencies of photosynthesis and stomatal conductance for the 2 wheatgrass species. Thus, the carbon gain and water loss rates of crested wheatgrass and bluebunch wheatgrass foliage do not account for their differences in grazing tolerance, and other factors such as production and maintenance of photosynthetic tissue are much more important.

\section{Literature Cited}

Barkworth, M.E., D.R. Dewey, and R.J. Atkins. 1983. New generic concepts in the Triticeae of the Intermountain region: Key and comments. Great Basin Natural. 43:561-572. 
Bingham, G.E., and P.I. Coyne. 1977. A portable, temperature-controlled, steady-state porometer for field measurements of transpiration and photosynthesis. Photosynthetica 11:148-160.

Caemmerer, S. von, and G.D. Farquhar. 1981. Some relationships between the biochemistry of photosynthesis and the gas exchange of leaves. Planta 153:376-387.

Caldwell, M.M., R.S. White, R.T. Moore, and L.B. Camp. 1977. Carbon balance, productivity, and water use of cold-winter desert shrub communities dominated by $C_{3}$ and $C_{4}$ species. Oecologia 29:275-300.

Caldwell, M.M., J.H. Richards, D.A. Johnson, R.S. Nowak, and R.S. Dzurec. 1981. Coping with herbivory: Photosynthetic capacity and resource allocation in 2 semiarid Agropyron bunchgrasses. Oecologia 50:14-24.

Caldwell, M.M, T.J. Dean, R.S. Nowak, R.S. Dzurec, and J.H. Richards. 1983. Bunchgrass architecture, light interception and water use: Assessment by fiber optic point quadrats and gas exchange. Oecologia 59:178-184.

Hyder, D.N. 1974. Morphogenesis and management of perennial grasses in the United States, p. 89-98. In: Plant Morphogenesis as the Basis for the Scientific Management of Range Resources. USDA Misc. Pub. No. 1271.

Larcher, W. 1980. Physiological plant ecology (second edition). SpringerVerlag, Berlin Heidelberg New York.

Neter, J., and W. Wasserman. 1974. Applied linear statistical models. Irwin Inc., Homewood, Ill.
Nowak, R.S. 1984. Plant gas exchange of 2 bunchgrasses in relation to herbivory tolerance. Ph.D. Diss., Utah State University, Logan.

Nowak, R.S., and M.M. Caldwell. 1984a. A test of compensatory photosynthesis in the field: Implications for herbivory tolerance. Oecologia 61:311-318.

Nowak, R.S., and M.M. Caldwell. 1984b. Photosynthetic capacity and survival of foliage during winter for 2 bunchgrass species in a cold-winter steppe environment. Photosynthetica 18:192-200.

Potvin. M.A., and P.A. Werner. 1983. Water use physiologies of cooccurring goldenrods (Solidago juncea and $S$. canadensis): Implications for natural distributions. Oecologia 56:148-152.

Schulze, E.D., and A.E. Hall. 1982. Stomatal responses, water loss and $\mathrm{CO}_{2}$ assimilation rates of plants in contrasting environments, p. 181-230. In: O.L. Lange, P.S. Nobel, C.B. Osmond, and H. Zeigler (eds.), Encyclopedia of Plant Physiology, new series, vol. 12B, Physiological Plant Ecology, part 2, Water Relations and Carbon Assimilation. SpringerVerlag. Berlin Heidelberg, New York.

Smith, E.L. 1937. The influence of light and carbon dioxide on photosynthesis. Gen. Physiol. 20:807-830.

Thomas, H. 1980. Terminology and definitions in studies of grassland plants. Grass Forage Sci. 35:13-23.

Wilson, G.L., and M.M. Ludlow. 1983. The distribution of leaf photosynthetic activity in a mixed grass-legume pasture canopy. Photosynthesis Res. 4:137-144. 